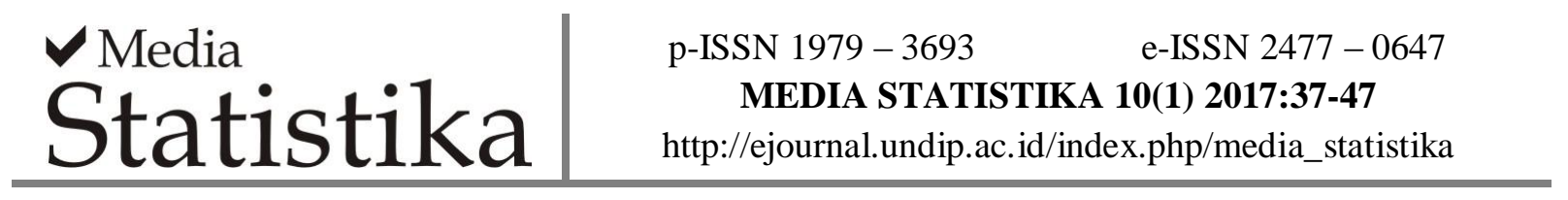

\title{
Penerapan Regresi Logistik Ordinal Proportional Odds Model pada Analisis Faktor-Faktor yang Mempengaruhi Kelengkapan Imunisasi Dasar Anak Balita di Provinsi Aceh Tahun 2015
}

\author{
Budyanra Budyanra ${ }^{1}$, Ghaida Nasria Azzahra ${ }^{2}$ \\ ${ }^{1}$ Sekolah Tinggi Ilmu Statistik - Jakarta \\ ${ }^{2}$ Badan Pusat Statistik \\ email: budy@stis.ac.id
}

DOI: 10.14710/medstat.10.1.37-47

\section{Article Info:}

Received: 11 Maret 2017

Accepted: 14 Juni 2017

Available Online: 14 Agustus 2017

Keywords:

Immunization, Ordinal Logistic Regression, Proportional Odds, Susenas

\begin{abstract}
Province of Aceh has basic immunization coverage toddler lowest in Indonesia in 2015. even though, this province has Posyandu and Puskesmas ratio per population of the highest in the western region of Indonesia. This data their concerns regarding immunization coverage has not been handled well in Aceh Province. This papers aims to identify variables that affect the status of complete basic immunization of children aged 12-59 months in Aceh by using ordinal logistic regression analysis. Ordinal logistic regression model used is proportional odds models. Data are obtained from Susenas 2015 that was held in March 2015 by BPS-Statistic of Indonesia. Based on the results of processing data, known only $37.7 \%$ of children aged 12-59 months in the province of Aceh in 2015 which gets fully immunized, the remaining $50.6 \%$ receive primary immunization but is not complete, even about $11.7 \%$ have not received basic immunization at all. From the proportional odds model results showed that the number of children born to mothers (odds ratio $=$ 0.88 ), maternal age at delivery (odds ratio $=1.03$ ), the level of maternal education (odds ratio $=1.22$ ), and the educational level of the household (odds ratio $=1,2$ ) have a significant impact on the status of complete basic immunization of children. Future studies are expected to include the element of timeliness and add other variables and also with other models in ordinal logistic regression.
\end{abstract}

\section{PENDAHULUAN}

Regresi logistik paling umum digunakan jika melibatkan sebuah variabel dependen dengan dua kategori, namun terdapat juga penelitian yang variabel dependennya memiliki lebih dari dua kategori. Dalam kasus seperti ini, analisis dapat dilakukan dengan menerapkan regresi logistik multinomial atau ordinal, tergantung pada ada atau tidaknya 
sifat berurutan pada variabel dependen. Untuk menganalisis variabel ordinal, regresi logistik ordinal dapat diterapkan. Regresi logistik multinomial, yang tidak mempertimbangkan sifat ordinal data, juga dapat diterapkan untuk meneliti sebuah variabel ordinal namun memanfaatkan sifat ordinal data dapat meningkatkan kesederhanaan dan kekuatan model (Agresti, 2002).

Terdapat berbagai pendekatan model yang dapat digunakan untuk menganalisis data ordinal, seperti model adjacent categories, continuation ratio, dan cumulative logit. Perbedaan dari model-model tersebut terletak pada cara pembentukkan logit (Agresti, 2010). Salah satu kelebihan model cumulative logit adalah estimasi efek yang tidak bervariasi antar pilihan dan jumlah kategori variabel dependennya (Agresti, 2010).

Pada keadaan variabel dependennya berkategorik ordinal, maka penggunaan metode regresi logistik ordinal menjadi sangat tepat untuk digunakan. Sehingga makalah ini bertujuan untuk menerapkan metode yang bisa mengakomodir analisis regresi logistik pada data dengan kategorik variabel dependennya ordinal menggunakan regresi logistik ordinal dengan model proportional odds. Penerapannya menggunakan data status kelengkapan imunisasi anak balita di Provinsi Aceh tahun 2015 beserta faktor-faktor yang mempengaruhinya.

\section{TINJAUAN PUSTAKA}

\subsection{Model Cumulative Logit}

Model cumulative logit yang memenuhi asumsi proportional odds merupakan model regresi ordinal yang paling umum digunakan karena menghasilkan estimasi yang cukup mudah untuk diinterpretasi (Lall, 2004). Selain itu, model ini memiliki sebuah sifat menarik yang tidak ditemukan pada model ordinal yang lain. Besar estimasi dalam model tersebut tidak bergantung pada arah model, apakah menuju kategori yang semakin tinggi atau rendah tingkatannya. Dengan kata lain, jika $Y_{1}$ dikodekan sebagai $Y_{\mathrm{J}}, \mathrm{Y}_{2}$ sebagai $\mathrm{Y}_{\mathrm{J}-1}$, dan seterusnya maka akan didapatkan nilai estimasi dengan besar yang sama dan arah yang berkebalikan. Sifat ini dikenal dengan nama palindromic invariance (Lall, 2004).

Jika regresi logistik biner terfokus pada peluang terjadinya suatu event, regresi logistik ordinal terfokus pada probabilitas kumulatif suatu event. Misalkan terdapat sebuah variabel ordinal dengan $J$ kategori dan $\pi_{0}, \pi_{1}, \ldots, \pi_{J}$ masing-masing merupakan peluang terjadinya kejadian $\mathrm{Y}=0, \mathrm{Y}=1, \ldots, \mathrm{Y}=\mathrm{J}$. Maka, probabilitas kumulatif terjadinya event ke-j atau lebih rendah adalah (Agresti, 2002):

$$
\mathrm{P}(\mathrm{Y} \leq \mathrm{j} \mid \mathrm{x})=\pi_{1}+\pi_{2}+\ldots+\pi_{\mathrm{j}}
$$

Maka, berdasarkan persamaan di atas, fungsi cumulative logit dapat didefinisikan sebagai (Agresti, 2002):

$$
\begin{aligned}
\operatorname{logit}[\mathrm{P}(\mathrm{Y} \leq \mathrm{j})] & =\ln \left[\frac{P(\mathrm{Y} \leq \mathrm{j})}{1-P(\mathrm{Y} \leq \mathrm{j})}\right] \\
& =\ln \left[\frac{\pi_{1}+\pi_{2}+\cdots+\pi_{j}}{\pi_{j+1}+\pi_{j+2}+\cdots+\pi_{J}}\right]
\end{aligned}
$$

Model cumulative logit sendiri terdiri dari tiga jenis model, yaitu model proportional odds, model partial proportional odds, dan model non proportional odds. Perbedaan utama dari ketiga model tersebut terletak pada penerapan asumsi paralelitas (Ari dan Yildiz, 2014). Pada model proportional odds, setiap cumulative logit memiliki intersepnya masing-masing, namun memiliki nilai efek $\beta$ yang sama (Agresti, 2002). Oleh 
karena itu, model ini memiliki sebuah asumsi yang penting, yaitu asumsi proportional odds, atau dikenal juga dengan nama asumsi parallel lines. Model non proportional odds menghasilkan nilai $\beta$ yang berbeda-beda untuk tiap cumulative logit (Ari dan Yildiz, 2014). Sementara itu, pada model partial proportional odds, sebagian variabel independen memiliki struktur proportional odds, dan sebagian lagi tidak (Agresti, 2010).

\subsection{Model Proportional Odds}

Pada model proportional odds, tiap cumulative logit memiliki nilai intersep $\alpha$ masing-masing, namun nilai estimasi parameter $\beta$ yang sama. Dengan kata lain, jika terdapat variabel dependen dengan jumlah kategori sebanyak J, maka akan terbentuk J-1 cumulative logit yang persis sama, hanya dibedakan oleh nilai intersepnya.

Sama seperti pada regresi logistik biner, transformasi logit dapat dilakukan untuk mendapatkan bentuk linier dari model proportional odds, yaitu:

$$
\begin{aligned}
\operatorname{logit}[\mathrm{P}(\mathrm{Y} \leq \mathrm{j} \mid \mathrm{x})] & =\ln \left[\frac{\mathrm{P}(\mathrm{Y} \leq \mathrm{j} \mid \mathrm{x})}{1-\mathrm{P}(\mathrm{Y} \leq \mathrm{j} \mid \mathrm{x})}\right]=\ln \left[\frac{\pi_{1}+\pi_{2}+\cdots+\pi_{j}}{\pi_{j+1}+\pi_{j+2}+\cdots+\pi_{J}}\right] \\
& =\ln \left[\exp \left(\alpha_{\mathrm{j}}+\beta_{1} \mathrm{X}_{1}+\ldots+\beta_{\mathrm{k}} \mathrm{X}_{\mathrm{k}}\right)\right]=\alpha_{\mathrm{j}}+\beta_{1} \mathrm{X}_{1}+\ldots+\beta_{\mathrm{k}} \mathrm{X}_{\mathrm{k}}
\end{aligned}
$$

Jika variabel dependen memiliki tiga kategori $(\mathrm{j}=1,2,3)$, maka model yang terbentuk adalah:

$$
\begin{aligned}
& \operatorname{logit}[P(Y \leq 1 \mid x)]=\alpha_{1}+\beta_{1} X_{1}+\ldots+\beta_{k} X_{k} \\
& \operatorname{logit}[P(Y \leq 2 \mid x)]=\alpha_{2}+\beta_{1} X_{1}+\ldots+\beta_{k} X_{k}
\end{aligned}
$$

Langkah-langkah analisis regresi logistik ordinal menggunakan model proportional odds adalah sebagai berikut:

\section{Estimasi Parameter}

Terdapat beberapa pendekatan yang dapat digunakan untuk mendapatkan nilai estimasi parameter $\alpha$ dan $\beta$. Model logistik merupakan model yang nonlinier, maka pendekatan yang paling populer digunakan adalah maximum likelihood estimation (MLE) (Kleinbaum dan Klein, 2010). Metode estimasi MLE tidak mensyaratkan jenis variabel independen, dengan kata lain ketika menggunakan metode estimasi MLE variabel independen dapat bersifat nominal, ordinal, maupun interval (Kleinbaum dan Klein, 2010).

Untuk melakukan prosedur MLE, pertama definisikan fungsi likelihood $\mathrm{L}(\beta)$, dimana $\beta$ merupakan parameter-parameter yang tidak diketahui dan diestimasikan dalam model. Fungsi likelihood menggambarkan joint probability untuk mendapatkan data yang telah dikumpulkan (Kleinbaum dan Klein, 2010). Fungsi likelihood untuk membentuk model logistik ordinal adalah sebagai berikut (Agresti, 2002):

$1(\beta)=\prod_{\mathrm{i}=1}^{\mathrm{n}} \prod_{\mathrm{j}=1}^{\mathrm{J}} \pi_{\mathrm{j}}\left(\mathrm{x}_{\mathrm{i}}\right)^{\mathrm{y}_{\mathrm{ji}}}=\prod_{\mathrm{i}=1}^{\mathrm{n}}\left\{\left[\pi_{1}\left(\mathrm{x}_{\mathrm{i}}\right)^{\mathrm{y}_{1 \mathrm{i}}}\right]\left[\pi_{2}\left(\mathrm{x}_{\mathrm{i}}\right)^{\mathrm{y}_{2 \mathrm{i}}}\right] \ldots\left[\pi_{\mathrm{J}}\left(\mathrm{x}_{\mathrm{i}}\right)^{\mathrm{y}_{\mathrm{Ji}}}\right]\right\}$

dimana $i=1,2, \ldots, n$ dan $j=1,2, \ldots, J$.

Kemudian, nilai estimasi dari $\beta$ yang dapat memaksimumkan nilai $1(\beta)$ dapat dicari. Hal ini dapat dilakukan dengan cara mendiferensialkan logaritma natural dari fungsi $1(\beta)$, kemudian disamadengankan dengan nol.

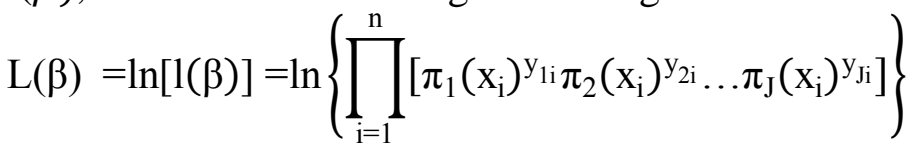




$$
=\sum_{\mathrm{i}=1}^{\mathrm{n}}\left\{\mathrm{y}_{1 \mathrm{i}} \ln \left[\pi_{1}\left(\mathrm{x}_{\mathrm{i}}\right)\right]+\mathrm{y}_{2 \mathrm{i}} \ln \left[\pi_{2}\left(\mathrm{x}_{\mathrm{i}}\right)\right]+\ldots+\mathrm{y}_{\mathrm{Ji}} \ln \left[\pi_{\mathrm{J}}\left(\mathrm{x}_{\mathrm{i}}\right)\right]\right\}
$$

Hasil dari proses diferensial tersebut merupakan fungsi nonlinier yang sulit untuk diselesaikan secara manual. Oleh karena itu, digunakan metode iterasi Fisher Scoring dengan program komputer untuk membantu perhitungan estimasi parameter (Agresti, 2002).

\section{Pengujian Asumsi Parallel Lines}

Dalam model proportional odds, terdapat sebuah asumsi penting yaitu asumsi parallel lines, yang berarti besar odds ratio tidak terpengaruh oleh dimana variabel dependen dikotomisasikan (Kleinbaum dan Klein, 2010). Maka, jika terdapat sebuah variabel dependen dengan jumlah kategori sebanyak J, hanya akan ada satu estimasi parameter $(\beta)$ untuk tiap variabel independen dan J-1 estimasi intersep $(\alpha)$ yang berbeda. Asumsi ini dapat diuji dengan menggunakan uji rasio log likelihood (Azen dan Walker, 2011). Hipotesis yang diajukan dalam pengujian ini adalah:

Ho: Model menghasilkan koefisien regresi (slope) yang sama

$\mathrm{H}_{1}$ : Model tidak menghasilkan koefisien regresi (slope) yang sama Statistik uji:

$$
P L=-2 \ln \left[\frac{l_{0}}{l_{1}}\right] \sim \chi_{\alpha, p(j-2)}^{2}
$$

Keterangan:

$l_{0}$ : fungsi likelihood dengan variabel independen yang mengasumsikan parallel lines.

$l_{1}$ : fungsi likelihood dengan variabel independen yang tidak mengasumsikan parallel lines.

Hipotesis nul ditolak ketika nilai $p$-value $<\alpha$ atau ketika nilai $P L>\chi_{\alpha, p(j-2)}^{2}$ dimana $\mathrm{p}$ adalah jumlah paramater dan $\mathrm{j}$ adalah jumlah kategori variabel dependen. Ketika hipotesis nul gagal ditolak, maka artinya slope pada kategori variabel independen bernilai sama dan asumsi parallel lines terpenuhi.

\section{Uji Kecocokan Model (Goodness of Fit Test)}

Pengujian goodness of fit bertujuan untuk mengetahui seberapa cocok model yang dihasilkan dengan data (Kleinbaum dan Klein, 2010). Hipotesis yang digunakan:

$\mathrm{H}_{0}$ : Model sesuai (fit) dengan data

$\mathrm{H}_{1}$ : Model tidak sesuai dengan data

Pengujian kecocokan model dapat dilakukan dengan membandingkan nilai yang diamati untuk suatu subjek dengan prediksi nilai untuk subjek tersebut (Kleinbaum dan Klein, 2010). Suatu model dikatakan memiliki kecocokan sempurna ketika nilai observasi dan prediksi sama untuk semua amatan. Ketika dalam model hanya terdapat sedikit variabel independen kategorik, maka sebuah tabel kontingensi dapat disusun dengan jumlah baris sebanyak pola kovariat dan jumlah kolom sebanyak kategori variabel dependen. Kemudian, nilai observasi dan estimasi dari masing-masing sel dapat dihitung dan pengujian kecocokan model dapat dilakukan menggunakan uji Pearson dan uji Deviance (Fagerland dan Hosmer, 2012). Kedua uji tersebut merupakan pengujian yang umum digunakan untuk model regresi logistik ordinal dan tersedia secara luas pada program-program pengolahan statistik.

Uji Pearson membandingkan nilai ekspektasi dan observasi tiap sel pada tabel kontingensi. Statistik uji untuk uji Pearson adalah (Agresti, 2010). Sementara itu, uji Deviance membandingkan likelihood model saturated dengan model yang didapat. Model saturated adalah model yang memiliki tingkat kecocokan sempurna (Kleinbaum dan Klein, 2010). Statistik uji untuk uji Deviance adalah (Agresti, 2010). Untuk kedua pengujian 
tersebut, hipotesis nul akan ditolak ketika nilai statistik uji yang didapat lebih besar dari $\chi_{\alpha, I-p-1}^{2}$ atau nilai $p$-value $<\alpha$, yang artinya model tidak sesuai dengan data.

\section{Uji Simultan (Uji Penduga Parameter secara Simultan)}

Pengujian secara simultan bertujuan untuk memeriksa peran variabel-variabel independen yang diajukan terhadap variabel dependen secara bersama-sama yang dapat dilakukan dengan menggunakan Uji Rasio Likelihood (Likelihood Ratio Test) (Hosmer, Lemeshow, dan Sturdivant, 2013). Hipotesis yang digunakan dalam pengujian ini adalah:

Statistik uji:

$$
\begin{aligned}
& \mathrm{H}_{0}: \beta_{1}=\beta_{2}=\cdots=\beta_{k}=0 \\
& \mathrm{H}_{1}: \text { Minimal ada satu } \beta_{k} \neq 0, \text { dimana } k=1,2, \ldots, p
\end{aligned}
$$

$G=-2 \ln \left[\frac{l_{0}}{l_{1}}\right] \sim \chi_{\alpha, p}^{2}$

Keterangan:

$l_{0}$ : nilai maksimum likelihood dari fungsi tanpa variabel independen (reduced model) $l_{1}$ : nilai maksimum likelihood dari fungsi dengan seluruh variabel independen (full model)

Hipotesis nul akan ditolak ketika $\mathrm{G}>\chi_{\alpha, p}^{2}$ atau nilai $p$-value $<\alpha$, yang berarti terdapat minimal satu variabel independen yang berpengaruh terhadap variabel dependen.

\section{Uji Parsial (Uji Penduga Parameter secara Parsial)}

Pengujian secara parsial bertujuan untuk menguji signifikansi masing-masing parameter, sehingga dapat diketahu mana variabel independen yang memiliki pengaruh nyata terhadap variabel dependen. Pengujian ini dapat dilakukan dengan uji Wald (Kutner, Nachtsheim, Neter, dan $\mathrm{Li}, 2004)$. Hipotesis yang digunakan dalam pengujian ini adalah:

$\mathrm{H}_{0}: \beta_{i}=0, \mathrm{i}=1,2, \ldots, \mathrm{k}$ (variabel independen ke-i tidak berpengaruh nyata terhadap variabel dependen)

$\mathrm{H}_{1}: \beta_{i} \neq 0, \mathrm{i}=1,2, \ldots, \mathrm{k}$ (variabel independen ke-i berpengaruh nyata terhadap variabel dependen)

Statistik uji:

$\left(z^{*}\right)^{2}=\left[\frac{\widehat{\beta}_{i}}{\operatorname{se}\left(\widehat{\beta}_{i}\right)}\right]^{2} \sim \chi_{\alpha, 1}^{2}$

Keterangan:

$\hat{\beta}_{i}$ : nilai estimasi parameter variabel independen ke-i

se $\left(\hat{\beta}_{i}\right)$ : nilai standar eror dari estimasi variabel independen ke-i

Hipotesis nul akan ditolak ketika $\left(z^{*}\right)^{2}>\chi_{\alpha, 1}^{2}$ atau nilai $p$-value $<\alpha$, yang berarti variabel independen ke-k berpengaruh terhadap variabel dependen.

\section{Penghitungan Nilai Odds Ratio}

Odds ratio $(\theta)$ menggambarkan kecenderungan suatu bagian populasi pada kategori tertentu terhadap bagian populasi pada kategori lainnya dalam suatu variabel independen yang memiliki pengaruh signifikan terhadap variabel dependen (Kleinbaum dan Klein, 2010). Pada logistik ordinal, odds ratio menggambarkan perbandingan antara odds dari berada pada atau dibawah sebuah kategori dengan odds berada di atas kategori tersebut. Odds ratio pada kategori $\mathrm{Y} \leq \mathrm{j}$ adalah perbandingan antara $\mathrm{x}_{\mathrm{i}}=1$ dan $\mathrm{x}_{\mathrm{i}}=0$ yaitu:

$\theta=\frac{(P \leq j \mid 1) /(P>j \mid 1)}{(P \leq j \mid 0) /(P>j \mid 0)}=\frac{\exp \left(\alpha_{j}+\beta_{i}\right)}{\exp \left(\alpha_{j}\right)}=\exp \left(\beta_{i}\right)$

Dalam model proportional odds, odds ratio menggambarkan perubahan (peningkatan atau penurunan) kecenderungan setiap pertambahan satu unit variabel 
independen, jika variabel independen tersebut kontinyu, atau perbedaan kecenderungan antar kategori, jika variabel independen bersifat kategorik (Hosmer, Lemeshow, dan Sturdivant, 2013).

\subsection{Imunisasi}

Imunisasi adalah suatu upaya untuk meningkatkan kekebalan seseorang secara aktif terhadap suatu penyakit. Sementara itu, imunisasi dasar adalah pemberian imunisasi awal untuk mencapai kadar kekebalan diatas ambang perlindungan (Kementerian Kesehatan RI, 2005). Berdasarkan peraturan dari Kementerian Kesehatan, kegiatan imunisasi dasar untuk bayi terdiri dari imunisasi BCG sebanyak 1 kali, DPT sebanyak 3 kali, Polio sebanyak 4 kali, Hepatitis B sebanyak 4 kali, dan Campak sebanyak 1 kali. Faktor-faktor yang Mempengaruhi Pemberian Imunisasi pada Anak:

a. Usia Ibu

Menurut Sampoerno dan Azwar (1987), ibu dengan usia yang lebih tua cenderung memiliki lebih banyak pengalaman dan informasi mengenai manfaat imunisasi bagi bayinya (Idwar, 2000).

b. Jumlah Anak

Memiliki anak yang banyak dapat menimbulkan keterbatasan sumber daya, yang memiliki dampak negatif pada pemanfaatan fasilitas kesehatan (Rahman, 2010). Jumlah anak juga akan mempengaruhi ada atau tidaknya waktu bagi ibu untuk mendapatkan pelayanan imunisasi bagi anaknya (Isfan, 2006).

c. Tingkat Pendidikan Ibu

Caldwell (1979) dalam Adebiyi (2013) menyatakan bahwa pendidikan ibu merupakan faktor penentu yang amat signifikan terhadap kesehatan anak, dan tidak ada faktor lain yang memiliki dampak sedemikian rupa. Adebiyi (2013) menemukan bahwa anak dari ibu yang menamatkan pendidikan menengah atau lebih tinggi 1,87 kali lebih cenderung untuk mendapatkan imunisasi lengkap dibandingkan dengan anak dari ibu yang tidak mendapatkan pendidikan.

d. Status Kerja Ibu

Steadfield dan Singarimbun (1986) menemukan di Indonesia bahwa ibu-ibu yang bekerja di luar rumah lebih cenderung untuk memberikan imunisasi pada anaknya dibandingkan dengan ibu-ibu yang tidak bekerja (Idwar, 2000).

e. Status Pekerjaan Kepala Rumah Tangga

Suami yang bekerja formal cenderung untuk memiliki pendidikan yang lebih baik dan dapat bertukar informasi dengan rekan-rekan kerjanya, sehingga lebih terpapar dengan program-program kesehatan, khususnya imunisasi (Isfan, 2006).

f. Tingkat Pendidikan Kepala Rumah Tangga

Pendidikan kepala keluarga akan berpengaruh terhadap tingkat kesehatan keluarga dan kemampuan memanfaatkan pelayanan kesehatan (Hastono, 2007). Menurut Mark (1979), status imunisasi anak akan lebih baik pada kepala keluarga yang mengenyam pendidikan lebih lama (Isfan, 2006).

\section{METODOLOGI PENELITIAN}

Penelitian ini menggunakan data sekunder, yaitu data mentah ( raw data) dari Survei Sosial Ekonomi Nasional (Susenas) 2015 yang dilaksanakan oleh Badan Pusat Statistik pada Maret 2015. Susenas mengumpulkan berbagai informasi mengenai kondisi sosial ekonomi masyarakat, termasuk yang dibutuhkan dalam penelitian ini seperti 
informasi imunisasi, pendidikan, dan ketenagakerjaan. Untuk mengetahui faktor-faktor yang mempengaruhi kelengkapan imunisasi dasar anak balita di Provinsi Aceh tahun 2015 maka digunakan analisis regresi logistik ordinal dengan model proportional odds. Model proportional odds digunakan jika asumsi parallel lines terpenuhi. Pada proses pengolahan data akan dibantu dengan program SPSS 20 dan Microsoft Excel 2013.

Variabel dependen dalam penelitian ini adalah status imunisasi anak usia 12-59 bulan. variabel dependen tersebut dibagi menjadi tiga kategori, yaitu:

1: Tidak diimunisasi

2: Diimunisasi tidak lengkap

3: Diimunisasi lengkap

Variabel independen dalam penelitian ini meliputi usia ibu saat melahirkan, tingkat pendidikan ibu, tingkat pendidikan kepala rumah tangga, status pekerjaan ibu, status pekerjaan kepala rumah tangga, dan jumlah anak lahir hidup ibu. Unit analisis dalam penelitian ini adalah anak berusia 12-59 bulan di Provinsi Aceh yang menjadi sampel pada Susenas 2015.

\section{HASIL DAN PEMBAHASAN}

Berdasarkan data yang diolah dari data mentah Susenas 2015, ditemukan sekitar 11,7\% anak usia 12-59 bulan di Provinsi Aceh tidak mendapatkan imunisasi dasar sama sekali, dan hanya 37,7\% anak yang telah mendapatkan imunisasi dasar lengkap. Sisanya, sebanyak 50,6\% pernah mendapatkan imunisasi dasar namun tidak lengkap.

\section{Hasil Analisis Regresi Logistik Ordinal Uji Asumsi Parallel Lines}

Hipotesis nul pada pengujian ini adalah model menghasilkan koefisien regresi (slope) yang sama untuk semua kategori status kelengkapan imunisasi anak. Jika hipotesis nul gagal ditolak, maka asumsi parallel lines dapat dikatakan terpenuhi.

Tabel 1. Hasil Penghitungan Nilai Statistik Uji Parallel Lines

\begin{tabular}{cccc}
\hline Chi-Square & Df & Chi-Square tabel & p-value \\
\hline 12,34 & 7 & 14,067 & 0,09 \\
\hline
\end{tabular}

Sumber: diolah dari data mentah Susenas 2015

Berdasarkan hasil penghitungan menggunakan persamaan (7), diperoleh nilai chisquare sebesar 12,34 dan p-value sebesar 0,09. Nilai ini masih lebih kecil dibandingkan nilai chi-square table $(14,06)$ sehingga keputusan yang diambil adalah gagal tolak Ho. Dengan demikian, pada tingkat kepercayaan $95 \%$ dapat dikatakan bahwa model yang dihasilkan memiliki koefisien regresi (slope) yang sama untuk semua kategori status imunisasi anak dan asumsi parallel lines terpenuhi. Sehingga model proportional odds cocok untuk digunakan.

\section{Uji Kesesuaian Model (Goodness of Fit)}

Hipotesis nul dalam pengujian ini adalah model yang dihasilkan sesuai dengan data, dengan kata lain model tersebut layak untuk digunakan dalam penelitian. Jika hipotesis nul gagal ditolak, maka dapat dikatakan bahwa model yang didapatkan sesuai dengan data.

Tabel 2. Hasil Penghitungan Uji Kesesuaian Model

\begin{tabular}{lcccc}
\hline \multicolumn{1}{c}{ Uji } & Chi-Square & df & Chi-Square tabel & p-value \\
\hline Pearson & 2477,25 & 2399 & 2514,06 & 0,13 \\
Deviance & 2476,73 & 2399 & 2514,06 & 0,13 \\
\hline
\end{tabular}

Sumber: diolah dari data mentah Susenas 2015 
Berdasarkan hasil penghitungan, diperoleh nilai chi-square Pearson sebesar 2477,25 dengan $p$-value 0,130. Sementara itu nilai chi-square Deviance sebesar 2476,73 dengan $p$-value 0,13 . Nilai tersebut masih lebih kecil dibandingkan nilai chi-square tabel sebesar 2514,06. Maka, keputusan yang diambil adalah gagal tolak Ho. Artinya, tidak ada cukup bukti untuk mengatakan bahwa model yang dihasilkan tidak sesuai dengan data.

Dari kedua pengujian tersebut semuanya mengarah pada kesimpulan bahwa model yang dihasilkan sesuai (fit) dengan data.

\section{Uji Penduga Parameter secara Simultan}

Hipotesis nul dalam pengujian ini adalah tidak ada variabel independen yang berpengaruh secara signifikan terhadap status kelengkapan imunisasi dasar anak. Jika hipotesis nul berhasil ditolak, maka dapat dikatakan bahwa minimal terdapat satu variabel independen yang secara signifikan mempengaruhi status kelengkapan imuniasasi dasar anak.

Tabel 3. Hasil Pengujian Secara Simultan

\begin{tabular}{lllll}
\hline Chi-Square & & Df & Chi-Square tabel & p-value \\
\hline 60,48 & 7 & & 14,06 & 0,000 \\
\hline
\end{tabular}

Sumber: diolah dari data mentah Susenas 2015

Berdasarkan hasil penghitungan dengan persamaan (8), diperoleh nilai chi-square sebesar 60,48 dengan $p$-value sebesar 0,000. Nilai tersebut lebih besar dibandingkan nilai chi-square tabel yaitu 14,06. Maka, keputusan yang diambil adalah tolak Ho. Dengan demikian, pada tingkat kepercayaan $95 \%$ dapat dikatakan bahwa minimal terdapat satu variabel independen yang mempengaruhi status kelengkapan imunisasi dasar anak secara signifikan.

\section{Uji Penduga Parameter secara Parsial}

Hipotesis nul dalam pengujian ini adalah variabel independen tertentu tidak berpengaruh secara signifikan terhadap status kelengkapan imuniasi dasar anak. Jika hipotesis nul berhasil ditolak, maka dapat dikatakan bahwa variabel independen tersebut mempengaruhi status imunisasi anak secara siginifikan.

Tabel 4. Penduga parameter regresi logistik ordinal dan signifikansinya

\begin{tabular}{lrr}
\hline \multicolumn{1}{c}{ Variabel } & Koefisien & p-value \\
\hline Jumlah anak lahir hidup ibu & $-0,125$ & 0,000 \\
Usia ibu saat melahirkan & 0,030 & 0,001 \\
Tingkat pendidikan ibu & 0,195 & 0,035 \\
Tingkat pendidikan kepala rumah tangga & 0,183 & 0,047 \\
Status pekerjaan ibu & 0,074 & 0,348 \\
Status pekerjaan kepala rumah tangga & 0,155 & 0,062 \\
Status kemiskinan rumah tangga & 0.151 & 0,167 \\
\hline \multicolumn{1}{c}{ Sumber: }
\end{tabular}

Sumber: diolah dari data mentah Susenas 2015

Berdasarkan penghitungan dengan persamaan (9), diketahui bahwa dari tujuh variabel yang diduga mempengaruhi status kelengkapan imunisasi anak, terdapat empat variabel yang memiliki nilai $p$-value kurang dari 0,05 yaitu variabel jumlah anak lahir hidup ibu, usia ibu saat melahirkan, tingkat pendidikan ibu dan tingkat pendidikan kepala rumah tangga. Artinya, pada tingkat kepercayaan $95 \%$ dapat dikatakan bahwa keempat variabel independen tersebut berpengaruh secara signifikan terhadap status kelengkapan imunisasi dasar anak. 
Setelah semua pengujian telah dilakukan, maka model regresi logistik ordinal dengan proportional odds yang terbentuk dapat ditentukan. Program pengolahan data dengan SPSS menyajikan arah yang terbalik pada output regresi logistik ordinal (Norusis,2011). Oleh karena itu untuk penulisan model, arah koefisien parameter harus dibalik arahnya. Persamaan regresi logistik ordinal yang terbentuk yaitu:

$$
\begin{aligned}
\operatorname{logit}[\mathrm{P}(\mathrm{Y} \leq 0 \mid \mathrm{x})]= & -1,401+0,03 \mathrm{usia} \_i b u *-0,125 j u m l a h \_a n a k^{*} \\
& +0,074 \text { pekerjaan_ibu }+0,195 \text { pendidikan_ibu* } \\
& +0,155 \text { pekerjaan }{ }_{\mathrm{krt}}+0,183 \text { pendidikan_krt* } \\
& +0,151 \text { status_miskin } \\
\operatorname{logit}[\mathrm{P}(\mathrm{Y} \leq 1 \mid \mathrm{x})]= & 1,191+0,03 \text { usia_ibu* }-0,125 \text { jumlah_anak* } \\
& +0,074 \text { pekerjaan_ibu }+0,195 \text { pendidikan_ibu* } \\
& +0,155 \text { pekerjaan_krt }+0,183 \text { pendidikan_krt* } \\
& +0,151 \text { status_miskin }
\end{aligned}
$$

\section{Penghitungan Nilai Odds Ratio}

Selanjutnya dilakukan penghitungan odds ratio untuk menghasilkan interpretasi yang lebih mudah dipahami. Penghitungan odds ratio hanya dilakukan untuk variabelvariabel yang signifikan saja.

Tabel 5. Nilai Odds Ratio Variabel Independen yang Signifikan

\begin{tabular}{ll}
\hline \multicolumn{1}{c}{ Variabel } & Odds Ratio \\
\hline Usia ibu saat melahirkan & 1,03 \\
Jumlah anak lahir hidup ibu & 0,88 \\
Tingkat pendidikan ibu & 1,22 \\
Tingkat pendidikan kepala rumah tangga & 1,20 \\
\hline
\end{tabular}

Sumber: diolah dari data mentah Susenas 2015

Berdasarkan hasil pengolahan, didapatkan nilai odds ratio untuk variabel usia ibu saat melahirkan sebesar $\exp (0,03)=1,03$. Artinya, terdapat peningkatan kecenderungan sebesar 1,03 kali untuk status imunisasi yang lebih baik setiap pertambahan usia ibu sebesar satu tahun. Dengan kata lain, semakin tua usia ibu saat melahirkan, semakin besar kemungkinan anaknya untuk memiliki status imunisasi yang lebih baik. Sementara itu, nilai odds ratio variabel jumlah anak lahir hidup ibu sebesar $\exp (-0,132)=0,88$. Sifat palindromic invariance dapat dimanfaatkan untuk memudahkan interpretasi, menghasilkan odds ratio sebesar $\exp (0,132)=1,14$. Artinya, terdapat peningkatan kecenderungan untuk status imunisasi yang lebih buruk sebesar 1,14 kali pada setiap pertambahan satu anak lahir hidup ibu. Dengan kata lain, semakin banyak jumlah anak lahir hidup seorang ibu maka semakin besar kemungkin anaknya untuk memiliki status imunisasi yang lebih buruk. Nilai odds ratio untuk variabel tingkat pendidikan ibu adalah $\exp (0,195)=1,22$. Artinya, anak dari ibu yang berpendidikan SMA/setara atau lebih tinggi memiliki kecenderungan 1,22 kali lebih besar untuk memiliki status imunisasi yang lebih baik dibandingkan anak dari ibu yang berpendidikan SMP/setara atau lebih rendah. Hubungan yang serupa ditemukan pada variabel pendidikan kepala rumah tangga. Nilai odds ratio untuk variabel tingkat pendidikan kepala rumah tangga adalah $\exp (0,183)=1,20$, yang berarti bahwa anak yang kepala rumah tangganya berpendidikan SMA/setara atau lebih tinggi memiliki 
kecenderungan 1,2 kali lebih besar untuk memiliki status imunisasi yang lebih baik dibandingkan anak yang kepala rumah tangganya berpendidikan SMP/setara atau lebih rendah dengan asumsi semua variabel lain dianggap konstan.

\section{KESIMPULAN DAN SARAN}

\subsection{Kesimpulan}

Berdasarkan dari hasil dan pembahasan penelitian, dapat ditarik beberapa kesimpulan sebagai berikut:

1. Variabel yang secara signifikan mempengaruhi status kelengkapan imunisasi dasar anak adalah usia ibu saat melahirkan, jumlah anak lahir hidup, tingkat pendidikan ibu, dan tingkat pendidikan kepala rumah tangga.

2. Variabel tingkat pendidikan ibu memiliki kecenderungan yang paling kuat dalam mempengaruhi status imunisasi anak.

3. Dari penggunaan metode regresi logistik ordinal dengan model proportional odds bisa diperoleh variabel-variabel yang secara signifikan mempengaruhi status kelengkapan imunisasi dasar anak balita di provinsi Aceh.

\subsection{Saran}

Berdasarkan kesimpulan di atas, maka saran yang dapat disampaikan adalah:

1. Perlunya perhatian khusus yang ditujukan untuk masyarakat Aceh dengan tingkat pendidikan yang lebih rendah, pekerja di sektor informal, ibu berusia muda, dan ibu dengan banyak anak agar lebih terdorong untuk berpartisipasi dalam program imunisasi.

2. Penelitian selanjutnya bisa melakukan penerapan model regresi ordinal lainnya jika asumsi parallel lines tidak terpenuhi.

\section{DAFTAR PUSTAKA}

Adebiyi, F., 2013. Determinants of full child immunization among 12-23 months old in Nigeria [Tesis]. Johannesburg: University of the Witwatersrand.

Agresti, A., 2002. Categorical Data Analysis (2nd ed). New Jersey: John Wiley \& Sons, Inc.

Agresti, A., 2010. Analysis of Ordinal Categorical Data (2nd ed). New Jersey: John Wiley \& Sons, Inc.

Ari, E. \& Yildiz, Z., 2014. Parallel lines assumption in ordinal logistic regression and analysis approaches. International Interdisciplinary Journal of Scientific Research, $1(3), 8-23$.

Azen, R \& Walker, C.M., 2011. Categorical data analysis for the behavioral and social sciences. New York: Taylor \& Francis Group.

Fagerland, M.W., \& Hosmer, D.W., 2012. A Goodness Of Fit Test For The Proportional Odds Regression Model. Journal Statistics in Medicine Vol 32, issue 13, 15 juni 2013 pages $2235-2249$

Hastono, S.P., 2009. Analisis data Riskesdas 2007/2008: kontribusi karakteristik ibu terhadap status imunisasi anak di Indonesia. Jurnal Kesehatan Masyarakat Nasional, 4(2), 91-96.

Hosmer, D.W., Lemeshow, S., \& Sturdivant, 2013. Applied Logistic Regression (3rd ed). New York: John Wiley \& Sons, Inc. 
Idwar, 2000. Faktor-Faktor yang Berhubungan dengan Status Imunisasi Hepatitis B pada Bayi (0-11 Bulan) di Kabupaten Aceh Besar Propinsi Daerah Istimewa Aceh Tahun 1998/1999 [Tesis]. Depok: Universitas Indonesia.

Isfan, R., 2006. Faktor-Faktor yang Berhubungan dengan Status Imunisasi Dasar pada Anak di Puskesmas Pauh Kota Padang Tahun 2006 [Tesis]. Depok: UI.

[Kemenkes] Kementerian Kesehatan RI., 2005. Keputusan Menteri Kesehatan Republik Indonesia Nomor 1611/Menkes/SK/IX/2005 tentang Pedoman Penyelenggaraan Imunisasi. Jakarta: Kementerian Kesehatan RI.

Kleinbaum, D.G. \& Klein, M., 2010. Logistic Regression: A Self Learning Text (3rd ed). New York: Springer.

Kutner, M.H., Nachtsheim, C.J., Neter, J., \& Li, W., 2004. Applied Linear Statistical Models $\left(5^{\text {th }}\right.$ ed). New York: McGraw-Hill/Irwin.

Lall, R., 2004. The Application of of Ordinal Regression Models ni Quality of Life Scales used in Gerontology [Tesis]. Sheffield: University of Sheffield.

Norusis, M.J., 2011. IBM SPSS Statistics 19 Advanced Statistical Procedures Companion. New Jersey: Prentice Hall.

Rahman, M., \& Obaida-Nasrin, S., 2010. Factors affecting acceptance of complete immunization coverage of children under five years in rural Bangladesh. Salud Publica de Mexico, 52, 134-140. 